\title{
Nomogram for second trimester corpus callosum measurements: are nomograms reliable?
}

\author{
Songül Alemdaroğlu (iD), Şafak Yılmaz Baran' (D), Gülşen Doğan Durdağ¹ (iD), Seda Yüksel Şimşek (iD), \\ Gonca Çoban Şerbetçioğlu² (iD) , Hakan Kalaycı ${ }^{1}$ \\ ${ }^{\prime}$ Department of Obstetrics and Gynecology, Adana Dr. Turgut Noyan Application and Research Center, School of Medicine, Başkent University, Adana, Turkey \\ ${ }^{2}$ Department of Obstetrics and Gynecology, Izmir Zïbeyde Hanım Application and Research Center, School of Medicine, Başkent University, Izmir, Turkey
}

\begin{abstract}
Objective: To define normal values of second trimester fetal corpus callosum (CC) length and width in a low-risk population and to compare the presented nomograms to those in the literature.

Methods: The prenatal records of singleton fetuses who underwent second trimester anomaly screening at 18.0-22.0 weeks of pregnancy were retrospectively analyzed for $\mathrm{CC}$ width and length. A total of 710 fetuses, whose anomaly scans were completely normal, were included in the study. The correlations between CC and biparietal diameter (BPD), head circumference (HC) and gestational age (GA) were evaluated.

Results: At 18.0-22.0 weeks of pregnancy, the mean CC length was $19.7 \pm 2.8 \mathrm{~mm}$, while the mean CC thickness was $1.98 \pm 0.4 \mathrm{~mm}$. In assessment of the correlations between the CC length and thickness values and the HC, BPD and GA values by Pearson's correlation coefficient, there was a stronger correlation between the CC length measurements and the BPD, HC and GA values ( $r=0.233$ vs $r=0.505$, $\mathrm{p}<0.001)$.

Conclusion: Assessment of the presence of corpus callosum as well as its length and thickness during routine fetal anomaly evaluation may be important owing to the relationship between corpus callosum measurements and certain neurological disorders. Studies indicate that populations should create their own nomograms due to different values reported in the literature.
\end{abstract}

Keywords: Corpus callosum, nomogram, low risk population, sonography.

\section{Introduction}

The corpus callosum (CC), the largest white matter structure in the human brain, is responsible for normal communication and cooperation between the two hemi-
Özet: İkinci trimester korpus kallozum ölçümleri için nomogram: Nomogramlar güvenilir mi?

Amaç: Düşük riskli bir popülasyonda ikinci trimester fetal korpus kallozum (KK) uzunluğunun ve genişliğinin normal değerlerinin belirlenmesi ve sunulan nomogramların literatür ile karşılaştırılması.

Yöntem: Gebeliğin 18-22. haftalarında ikinci trimester anomali taraması yapılan tekil fetüslerin prenatal kayıtları KK genişliği ve uzunluğu yönünden retrospektif olarak analiz edildi. Yalnızca anomali taramaları tamamen normal bulunan toplam 710 fetüs çalışmaya dahil edildi. KK ile bipariyetal çap (BPÇ), baş çevresi (BÇ) ve gestasyonel yaş (GY) arasındaki korelasyonlar değerlendirildi.

Bulgular: Gebeliğin 18-22. haftasında ortalama KK uzunluğu $19.7 \pm 2.8 \mathrm{~mm}$ ve ortalama KK kalınlığ $1.98 \pm 0.4 \mathrm{~mm}$ olarak bulundu. KK uzunluğu ve kalınlığı ile BÇ, BPÇ ve GY değerleri arasındaki korelasyonların Pearson korelasyon katsayısı ile değerlendirilmesinde, KK uzunluk ölçümleri ile BPÇ, BÇ ve GY değerleri arasında güçlü bir korelasyon tespit edildi ( $r=0.233$ 'e karşı $r=0.505$, $\mathrm{p}<0.001)$.

Sonuç: Rutin fetal anomali değerlendirmesinde korpus kallozumun varlığının yanı sıra uzunluğunun ve kalınlığının değerlendirilmesi, korpus kallozum ölçümleri ile belirli nörolojik bozukluklar arasındaki ilişki nedeniyle önemli olabilir. Yapılan çalışmalar, literatürde bildirilen farklı değerler nedeniyle her popülasyona özgü nomogramlar oluşturulması gerektiğini göstermektedir.

Anahtar sözcükler: Korpus kallozum, nomogram, düşük riskli popülasyon, sonografi.

spheres. ${ }^{[1]}$ As a birth defect, agenesis of the corpus callosum (ACC) occurs in over 50 different human congenital syndromes. ${ }^{[2]} \mathrm{CC}$ develops between 11 and 15 weeks of gestation with a process, and the final shape of $\mathrm{CC}$ is

\footnotetext{
Correspondence: Songül Alemdaroğlu, MD. Department of Obstetrics and Gynecology, Adana Dr. Turgut Noyan Application and Research Center, School of Medicine, Başkent University, Adana, Turkey. e-mail: songul_aykul@hotmail.com / Received: August 16, 2020; Accepted: October 7, 2020 Please cite this article as: Alemdaroğlu S, Baran ŞY, Doğan Durdağ G, Yüksel Şimşek S, Çoban Şerbetçioğlu G, Kalaycı H. Nomogram for second trimester corpus callosum measurements: are nomograms reliable? Perinatal Journal 2020;28(3):196-201. doi:10.2399/prn.20.0283011
} 
complete only at 20 weeks of gestation, while it continues to grow and develop until adolescence. ${ }^{[3]}$ The reported prevalence of these anomalies ranges from 1.8 per 10,000 in the general population to $230-600$ per 10,000 in children with neurodevelopmental disabilities. ${ }^{[4]}$ Some of these individuals are more susceptible to behavioral and neuropsychiatric problems, and thus, learning difficulties, ${ }^{[5]}$ sleep disorders, ${ }^{[6]}$ language and social communication disorders ${ }^{[7]}$ and visuospatial attention deficits. ${ }^{[8]}$ However, there is insufficient information about the effects of the presence of a thinner or thicker, longer or shorter corpus callosum in the fetus than normal.

$\mathrm{CC}$ is anatomically defined in 4 regions: the rostrum, the genu, the body and the splenium. There are different terminologies used to identify $\mathrm{CC}$ anomalies. The most common anomalies are agenesis (partial: for example, in only the rostral or the splenium region, or complete), hypoplasia (fully formed but thinner), hyperplasia (fully formed but thicker) or dysplasia. ${ }^{[9]}$

Several different CC nomograms have been presented in the literature. ${ }^{[10-17]}$ The fact that the values presented in these nomograms are very different from each other emphasizes that different regions/populations will have different values. The different results obtained even in studies with similar measurement techniques reveal the necessity for populations to create their own nomograms. For this reason, our aim is to determine the nomogram of corpus callosum measurements in fetuses in a low-risk Turkish population with normal anomaly scans at 18.0-22.0 weeks of pregnancy with normal systemic and neurological examinations. The values were compared to the nomograms presented in the literature.

\section{Methods}

The data of 4728 patients who gave birth in the period of 2015-2018 at our hospital were retrospectively reviewed. The records of patients who gave birth at 37 weeks or later based on their last date of menstruation under elective conditions and had singleton pregnancies were examined. By including newborns whose first systemic and neurological examinations after birth were normal, their files were examined to assess their pregnancy follow ups. Among these patients, those who had their all antenatal follow ups including the 18-22-week fetal anomaly screening done at our center and had fetal growth correlated with their crown lump length (CRL) in the 1st trimester and biparietal diameter (BPD) and head circumference $(\mathrm{HC})$ measurements in the $2 \mathrm{nd}$ and 3rd trimesters were included in the study. Patients for whom emergency labor was planned due to reasons such as preeclampsia and fetal distress, those in whom fetal anomaly was determined, those who were being monitored due to detection of uncontrolled diabetes, intrauterine developmental retardation (estimated fetal weight $[\mathrm{EFW}]$ ) of under 10th percentile in ultrasonography) and those who did not have CC measurement images in their files were excluded from the study.

Fetal evaluation consisted of a standard complete anatomical survey as in second-trimester anomaly scans. All ultrasound examinations were performed with a Voluson E8 device (5- to $8-\mathrm{MHz} 3 \mathrm{D}$ transducer: General Electric Healthcare, Little Chalfont, UK) via the transabdominal route. The patients in whom the 4 parts of CC (the rostrum, the genu, the body and the splenium) could not be clearly examined during fetal anomaly screening were not included in the study. The CC images of all patients were examined from their files. In the midsagittal view, the corpus callosum length was measured from the anterior part of the genu to the posterior part of the splenium, and the width was measured from the thickest area of the corpus (Fig. 1). Calipers were placed at the inner border of CC during the measurements. Each fetus was included only once. The fetuses were not mentioned as male or female.

University Institutional Review Board (IRB) approved the research protocol, and the study was supported by the University Research Fund (project no: KA17/203). Due to the retrospective nature of the study, informed consent was not applicable.

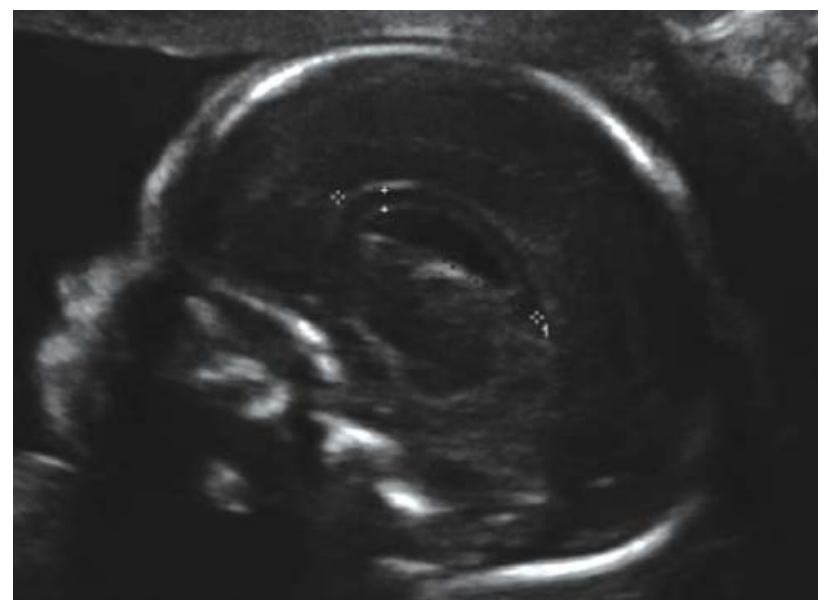

Fig. 1. Measurement of corpus callosum length and width. 
Table 1. Length of fetal corpus callosum by gestational age.

\begin{tabular}{lcccccc} 
Gestational age (weeks) & Observations $\mathbf{( n )}$ & $\begin{array}{c}\text { Lower } \\
\mathbf{9 5 \%} \mathbf{C l}\end{array}$ & $\begin{array}{c}\text { Mean length } \\
\mathbf{( m m )}\end{array}$ & $\begin{array}{c}\text { Upper } \\
\mathbf{9 5 \%} \mathbf{~ C l}\end{array}$ & Min & Max \\
\hline $18.0-18.6$ & 75 & 17.17 & 18.05 & 18.93 & 11.10 & 27.76 \\
\hline $19.0-19.6$ & 221 & 17.95 & 18.27 & 18.58 & 11.64 & 27.14 \\
\hline $20.0-20.6$ & 262 & 19.86 & 20.15 & 20.44 & 14.26 & 29.90 \\
\hline $21.0-21.6$ & 139 & 21.33 & 21.68 & 22.04 & 15.12 & 26.68 \\
\hline 22.0 & 13 & 22.37 & 23.52 & 24.66 & 20.49 & 27.14 \\
\hline
\end{tabular}

Table 2. Thickness of fetal corpus callosum by gestational age.

\begin{tabular}{|c|c|c|c|c|c|c|}
\hline Gestational age (weeks) & Observations ( $n$ ) & $\begin{array}{l}\text { Lower } \\
95 \% \mathrm{Cl}\end{array}$ & $\begin{array}{l}\text { Mean thickness } \\
(\mathrm{mm})\end{array}$ & $\begin{array}{l}\text { Upper } \\
95 \% \text { CI }\end{array}$ & Min & Max \\
\hline $18.0-18.6$ & 75 & 1.78 & 1.89 & 1.99 & 0.97 & 2.91 \\
\hline $19.0-19.6$ & 221 & 1.84 & 1.90 & 1.96 & 1.09 & 4.47 \\
\hline $20.0-20.6$ & 262 & 1.92 & 1.97 & 2.01 & 1.08 & 3.41 \\
\hline $21.0-21.6$ & 139 & 2.11 & 2.18 & 2.25 & 1.00 & 3.13 \\
\hline 22.0 & 13 & 1.96 & 2.13 & 2.30 & 1.69 & 2.69 \\
\hline
\end{tabular}

\section{Statistical method}

Based on the gestational age of pregnancy, the mean, $95 \%$ confidence interval for the mean, and minimum and maximum values of $\mathrm{CC}$ length and thickness were calculated. Additionally, the correlations between the CC length and thickness values and the BPD, HC and GA values were calculated by using Pearson's correlation coefficient. In the analyses, the IBM SPSS Statistics Version 20.0 package program (IBM, Armonk, NY, USA) was utilized. The level of statistical significance was taken as 0.05 in all tests.

\section{Results}

A total of 710 patients who met the inclusion criteria between 18.0 and 22.0 weeks of gestation were included in the study. The participants' mean gestational age was $20.0 \pm 0.9$ weeks. At the gestational weeks of $18.0-22.0$, the mean CC length was $19.7 \pm 2.8$ (range: $11.1-29.9$ ) $\mathrm{mm}$, while the mean CC thickness was $1.98 \pm 0.4$ (range: $0.97-4.47) \mathrm{mm}$. The CC length and thickness values based on gestational age are given in Tables $\mathbf{1}$ and $\mathbf{2}$.

The CC length and thickness measurements were compared to the BPD, HC and GA values in linear regression tests. There was no significant correlation between the CC thickness measurements and the HC, BPD and GA values $(r<0.3)$. The correlation between the CC length measurements and the HC, BPD and GA values was found to be stronger than the $\mathrm{CC}$ thickness measurements, but still weak ( $\mathrm{r}=0.5)$ (Table 3).

\section{Discussion}

An appropriate growth pattern of CC development is important as it is accepted as an indicator of normal brain development and maturation. ${ }^{[18]}$ This is why it is recommended to assess $\mathrm{CC}$ in the midsagittal plane during fetal anomaly screening between 18.0 and 22.0 weeks of pregnancy. ${ }^{[19,20]}$

The most frequently utilized technique in CC imaging is utilization of the metopic suture acoustic window of the trans-frontal image in the midsagittal plane with the transabdominal or transvaginal route. In CC imag-

Table 3. The correlation between CC length and thickness measurements and $\mathrm{HC}, \mathrm{BPD}$, and $\mathrm{GA}$ values.

\begin{tabular}{lcc} 
All pregnancies & Correlation coefficient & p-value \\
\hline CC-length - GA & 0.505 & $<0.001$ \\
\hline CC-thickness - GA & 0.233 & $<0.001$ \\
\hline CC-length - BPD & 0.444 & $<0.001$ \\
\hline CC-thickness - BPD & 0.252 & $<0.001$ \\
\hline CC-length - HC & 0.499 & $<0.001$ \\
\hline CC-thickness - HC & 0.229 & $<0.001$ \\
\hline
\end{tabular}




\begin{tabular}{|c|c|c|c|c|c|c|}
\hline & 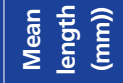 & $\begin{array}{l}n \\
0 \\
\infty \\
\infty \\
\infty\end{array}$ & $\begin{array}{l}\tilde{\nwarrow} \\
\infty \\
\infty\end{array}$ & $\stackrel{n}{\stackrel{n}{c}}$ & $\stackrel{m}{\stackrel{m}{\sim}}$ & $\underset{\substack{n \\
\sim}}{\sim}$ \\
\hline 造 & 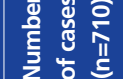 & $\stackrel{n}{\wedge}$ & $\overline{\mathbb{N}}$ & $\underset{\sim}{\widetilde{N}}$ & $\stackrel{\stackrel{p}{\sim}}{-}$ & $\stackrel{m}{=}$ \\
\hline
\end{tabular}

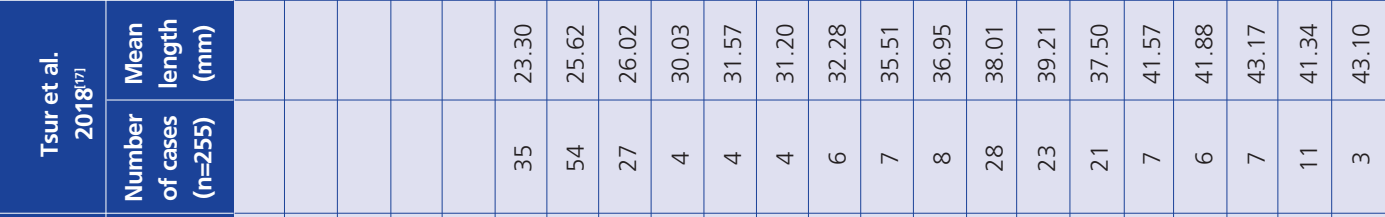

\begin{tabular}{|c|c|c|c|c|c|c|c|c|c|c|c|c|c|c|c|c|c|c|c|c|c|c|c|}
\hline ๙ & $m$ & $\stackrel{\infty}{\stackrel{m}{m}}$ & $\stackrel{m}{=}$ & t. & $\overline{\ddot{n}}$ & $\stackrel{\text { nn }}{\sim}$ & $\hat{\grave{i}}$ & กิ & $\stackrel{+}{m}$ & $\stackrel{\circ}{m}$ & 广্ & 它 & $\hat{i}$ & $\begin{array}{l}0 \\
\dot{m} \\
\end{array}$ & $\underset{\infty}{\oplus}$ & - & ㅎ. & r̃ & $\begin{array}{ll}n \\
q \\
q\end{array}$ & $\begin{array}{l}\infty \\
\dot{q} \\
\dot{q}\end{array}$ & 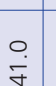 & $\bar{z}$ & 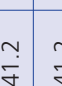 \\
\hline 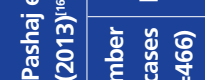 & 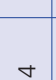 & $\infty$ & $\sigma$ & $m$ & $\stackrel{\Delta}{\triangle}$ & $\cong$ & $\stackrel{\sim}{\Omega}$ & $\sigma$ & $\bar{N}$ & $\approx$ & $\bar{N}$ & $\mathscr{N}$ & $\stackrel{n}{\sim}$ & $\stackrel{n}{\sim}$ & 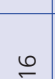 & $\approx$ & $\stackrel{\sim}{\sim}$ & $\stackrel{\stackrel{\sim}{\sim}}{ }$ & 요 & $\stackrel{m}{\sim}$ & $\underline{\sigma}$ & ㄱ & $\stackrel{\sim}{\sim}$ \\
\hline
\end{tabular}

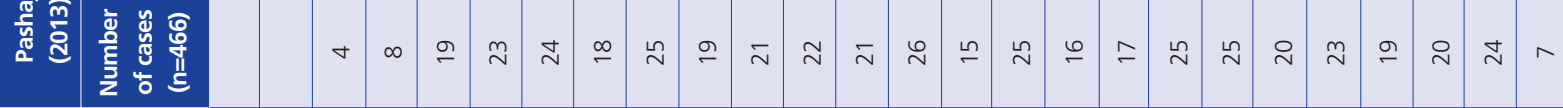

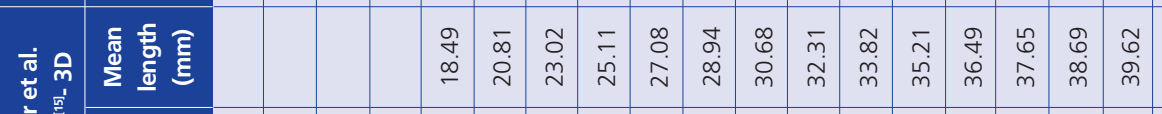

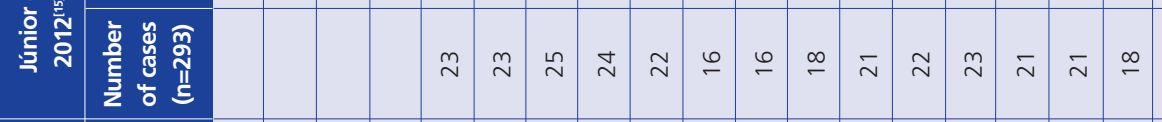

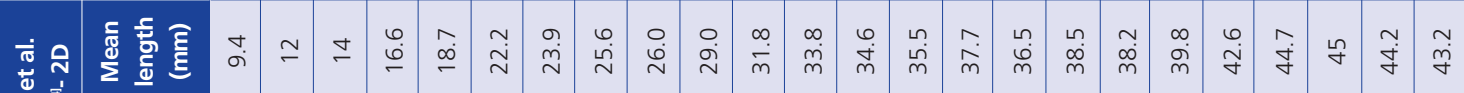

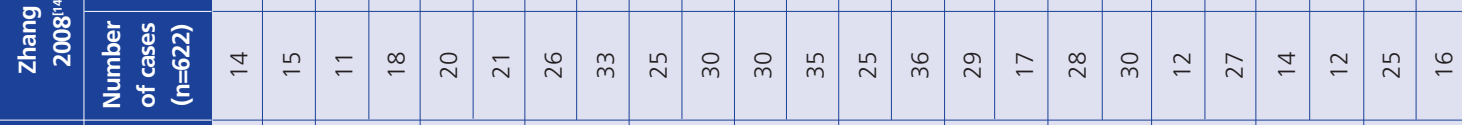

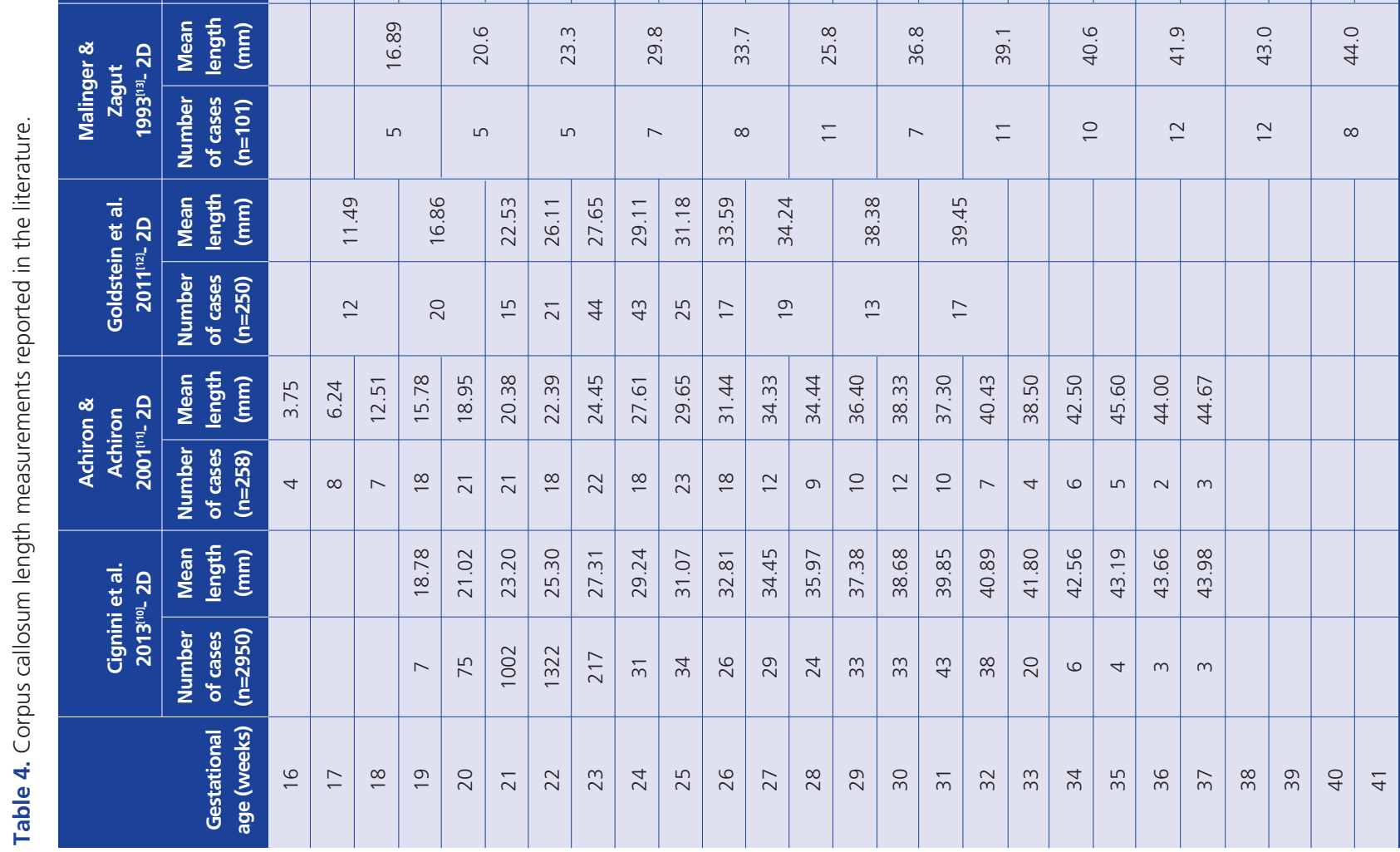


ing with $3 \mathrm{D}$ probes, higher success rates were reported as it does not require a complete midsagittal plane, and multiplanar images can be obtained (2D vs $3 \mathrm{D}: 74-76 \%$ vs $100 \%) .{ }^{[13,21]}$ However, as it requires special training regarding probe usage, and as not every clinic has $3 \mathrm{D}$ probes, but all have $2 \mathrm{D}$ probes, our study was kept limited to $2 \mathrm{D}$ measurements. CC anomalies may be in the form of complete structural absence of CC (agenesis), partial absence, hypoplasia or dysplasia. The outcomes of CC anomalies cannot be predicted and are highly variable. $^{[22]}$ While they may show comorbidity with motor control, language and learning disorders, they may also be seen in children with completely normal neurodevelopmental characteristics. ${ }^{[23]}$ While diagnosis is easier in agenesis of CC, fetal nomograms are needed for the diagnosis of dysgenesis. Since hypoplastic CC development has been shown in the etiology of autism, epilepsy and movement disorders, during neuroanatomical assessment, assessing not only the entire presence of CC but also its developmental process has become compulsory. ${ }^{[24-26]}$ Table 4 shows CC nomograms prepared by different researchers. ${ }^{[10-17]}$ As seen in the table, there are societal differences among such studies (Table 4). This situation not only reveals the necessity for different populations to develop their own nomograms, but it also requires questioning of the diagnostic accuracy of nomograms. Are nomograms reliable with such different measurements? The most reliable studies that will prove the accuracy of nomograms are those that will be carried out with patients whose antenatal, postnatal, childhood neurological developments and academic success are monitored. The existing studies in the literature and our study could only be a small beginning for such studies.

Zhang et al.' $\mathrm{s}^{[14]}$ nomogram in a Chinese population revealed a strong correlation between GA and CC measurements $(r=0.932, p<0.001)$. Finding a weaker correlation between the GA and CC measurements in our study is believed to have been caused by the fact that the patient group was into their 18.0-22.0 weeks of pregnancy $(\mathrm{r}=0.505, \mathrm{p}<0.001)$ while Zhang's population was between 16 and 19 weeks of gestation. Chasen et al. reported the maximal CC growth at the 19.6 week of pregnancy. ${ }^{[27]}$ Nomograms are usually obtained between 18 and 22 weeks of gestation, when detailed assessments for fetal anomalies are frequently made. As detection of $\mathrm{CC}$ anomalies where outcomes are variable in a fetus within living limits and termination based on these are medically and ethically under debate, our study was kept limited to the weeks 18.0-22.0 of pregnancy, where fetal anomaly screening is recommended for nomogram weeks (Supplementary materials: $S$-Table 1 . The percentiles of the measurement of CC length ( $\mathrm{mm}$ ) by gestational week; S-Table 2. The percentiles of the measurement of CC thickness (mm) by gestational week \& S-Fig. 1. Polynominal regression analysis and scatter graph.)

The most important limitation of our study was that the postpartum neurodevelopmental monitoring of the children was not carried out. However, although several children with CC anomalies share similar neuroanatomical profiles, their neurodevelopmental outcomes are highly variable. There are also contradictions among studies due to the heterogeneity in assessment of neurodevelopmental outcomes. ${ }^{[23]}$ The reason for keeping the CC measurement limited between the 18 and 22 weeks was that, in patients whose fetal anomaly screening was assessed to be normal, and where fetal growth progressed normally during antenatal follow up to the delivery, CC assessment would not be performed again. This situation led us to focus on the 18.0-22.0 weeks of antenatal follow up.

\section{Conclusion}

This study provides normal ranges of CC measurements between 18.0 and 22.0 weeks of pregnancy in a low-risk population. Reference values for the corpus callosum are important for evaluation of brain development. A reduced CC size may be correlated with a low IQ, poor motor and language performance and neuropsychological impairment in childhood. It is important that communities report their own nomograms because of differences in previously reported values.

Conflicts of Interest: No conflicts declared.

\section{References}

1. Bloom JS, Hynd GW. The role of the corpus callosum in interhemispheric transfer of information: excitation or inhibition? Neuropsychol Rev 2005;15:59-71. [PubMed] [CrossRef]

2. Norman MG, McGillivray BC, Kalousek DK, Hill A, Poskitt KJ. Congenital malformations of the brain: pathological, embryological, clinical, radiological and genetic aspects. New York, NY: Oxford University Press; 1995.

3. Edwards TJ, Sherr EH, Barkovich AJ, Richards LJ. Clinical, genetic and imaging findings identify new causes for corpus callosum development syndromes. Brain 2014;137:1579_ 613. [PubMed] [CrossRef]

4. Palmer EE, Mowat D. Agenesis of the corpus callosum: a clinical approach to diagnosis. Am J Med Genet Part C Semin Med Genet 2004;166C:184-97. [PubMed] [CrossRef] 
5. Párraga HC, Párraga MI, Jensen AR. Cognitive, behavioral, and psychiatric symptoms in two children with agenesis of the corpus callosum: case report. Int J Psychiatry Med 2003;33:107-13. [PubMed] [CrossRef]

6. Nielsen T, Montplaisir J, Lassonde M. Sleep architecture in agenesis of the corpus callosum: laboratory assessment of four cases. J Sleep Res 1992;1:197-200. [PubMed] [CrossRef]

7. Paul LK, Van Lancker-Sidtis D, Schieffer B, Dietrich R, Brown WS. Communicative deficits in agenesis of the corpus callosum: nonliteral language and affective prosody. Brain Lang 2003;85:313-24. [PubMed] [CrossRef]

8. Hines RJ, Paul LK, Brown WS. Spatial attention in agenesis of the corpus callosum: shifting attention between visual fields. Neuropsychologia 2002;40:1804-14. [PubMed] [CrossRef]

9. Leombroni M, Khalil A, Liberati M, D'Antonio F. Fetal midline anomalies: diagnosis and counseling. Part 1: corpus callosum anomalies. Eur J Paediatr Neurol 2018;22:951-62. [PubMed] [CrossRef]

10. Cignini P, Padula F, Giorlandino M, Brutti P, Alfò $M$, Giannarelli D, et al. Reference charts for fetal corpus callosum length: a prospective cross-sectional study of 2950 fetuses. J Ultrasound Med 2014;33:1065-78. [PubMed] [CrossRef]

11. Achiron R, Achiron A. Development of the human fetal corpus callosum: a high-resolution, cross-sectional sonographic study. Ultrasound Obstet Gynecol 2001;18:343-7. [PubMed] [CrossRef]

12. Goldstein I, Tamir A, Reece AE, Weiner Z. Corpus callosum growth in normal and growth-restricted fetuses. Prenat Diagn 2011;31:1115-9. [PubMed] [CrossRef]

13. Malinger G, Zakut H. The corpus callosum: normal fetal development as shown by transvaginal sonography. Am J Roentgenol 1993;161:1041-3. [PubMed] [CrossRef]

14. Zhang HC, Yang J, Chen ZP, Ma XY. Sonographic study of the development of fetal corpus callosum in a Chinese population. J Clin Ultrasound 2009;37:75-7. [PubMed] [CrossRef]

15. Júnior EA, Visentainer M, Simioni C, Ruano R, Nardozza LMM, Moron AF. Reference values for the length and area of the fetal corpus callosum on 3-dimensional sonography using the transfrontal view. J Ultrasound Med 2012;31:205-12. [PubMed] [CrossRef]

16. Pashaj S, Merz E, Wellek S. Biometry of the fetal corpus callosum by three-dimensional ultrasound. Ultrasound Obstet Gynecol 2013;42:691-8. [PubMed] [CrossRef]
17. Tsur A, Weisz B, Rosenblat O, Shai D, Derazne E, Stevenson DK, et al. Personalized charts for the fetal corpus callosum length. J Matern Fetal Neonatal Med 2019;32: 3931-8. [PubMed] [CrossRef]

18. Barkovich AJ, Norman D. Anomalies of the corpus callosum: correlation with further anomalies of the brain. Am J Roentgenol 1988;151:171-9. [PubMed] [CrossRef]

19. Salomon L, Alfirevic Z, Berghella V, Bilardo C, HernandezAndrade E, Johnsen S, et al.; ISUOG Clinical Standards Committee. Practice guidelines for performance of the routine mid-trimester fetal ultrasound scan. Ultrasound Obstet Gynecol 2011;37:116-26. [PubMed] [CrossRef]

20. International Society of Ultrasound in Obstetrics \& Gynecology Education Committee. Sonographic examination of the fetal central nervous system: guidelines for performing the 'basic examination' and the 'fetal neurosonogram'. Ultrasound Obstet Gynecol 2007;29:109-16. [PubMed] [CrossRef]

21. Monteagudo A, Reuss ML, Timor-Tritsch IE. Imaging the fetal brain in the second and third trimesters using transvaginal sonography. Obstet Gynecol 1991;77:27-32. [PubMed]

22. Paul LK. Developmental malformation of the corpus callosum: a review of typical callosal development and examples of developmental disorders with callosal involvement. J Neurodev Disord 2011;3:3-27. [PubMed] [CrossRef]

23. D'Antonio F, Pagani G, Familiari A, Khalil A, Sagies T-L, Malinger $\mathrm{G}$, et al. Outcomes associated with isolated agenesis of the corpus callosum: a meta-analysis. Pediatrics 2016;138: e20160445. [PubMed] [CrossRef]

24. Lisy J, Efremova A, Hrdlicka M. The yield of structural magnetic resonance imaging in autism spectrum disorders. Biomed Pap Fac Univ Palacky Olomouc Czech Repub 2019;163:3748. [PubMed] [CrossRef]

25. Wegiel J, Flory M, Kaczmarski W, Brown WT, Chadman K, Wisniewski T, et al. Partial agenesis and hypoplasia of the corpus callosum in idiopathic autism. J Neuropathol Exp Neurol 2017;76:225-37. [PubMed] [CrossRef]

26. Margari L, Palumbi R, Campa MG, Operto FF, Buttiglione $\mathrm{M}$, Craig F, et al. Clinical manifestations in children and adolescents with corpus callosum abnormalities. J Neurol 2016;263:1939-45. [PubMed] [CrossRef]

27. Chasen S, Birnholz J, Gurewitsch E, Skupski D, Chervenak F. Antenatal growth of the corpus callosum. Am J Obstet Gynecol 1997;176(1 Pt 2):S66. [CrossRef]

\section{Supplementary materials:}

Supplemental digital content is available for this article, which is available at www.perinataljournal.com

$S$-Table 1. The percentiles of the measurement of CC length ( $\mathrm{mm})$ by gestational week.

$S$-Table 2. The percentiles of the measurement of CC thickness $(\mathrm{mm})$ by gestational week.

S-Fig. 1. Polynominal regression analysis and scatter graph.

Bu makalenin kullanım izni Creative Commons Attribution-NoCommercial-NoDerivs 3.0 Unported (CC BY-NC-ND3.0) lisansı aracilığıyla bedelsiz sunulmaktadir. / This work is licensed under the Creative Commons Attribution-NonCommercial-NoDerivs 3.0 Unported (CC BY-NC-ND3.0) License. To view a copy of this license, visit http://creativecommons.org/licenses/by-nc-nd/3.0/ or send a letter to Creative Commons, PO Box 1866, Mountain View, CA 94042, USA. 